\title{
CHARACTERIZATION AND PATHOGENICITY OF Rhizoctonia SPP. ISOLATED FROM VEGETABLE CROPS GROWN IN GREENHOUSES IN SAMSUN PROVINCE, TURKEY
}

\author{
CARACTERIZAÇÃO E PATOGENICIDADE DE Rhizoctonia SPP. ISOLADA A \\ PARTIR DE CULTURAS VEGETAIS CRESCIDAS EM ESTUFAS NA PROVÍNCIA DE \\ SAMSUN, TURQUIA
}

Elif YILDIRIM ${ }^{1}$; Ismail ERPER ${ }^{1}$

1. Department of Plant Protection, Faculty of Agriculture, Ondokuz Mayis University, 55139 Samsun, Turkey, ismailer@omu.edu.tr

\begin{abstract}
A total of one hundred and five isolates of Rhizoctonia belonging to 7 anastomosis groups (AGs) were obtained from the diseased roots and rhizosphere soils of bean, cucumber, eggplant, pepper and tomato plants grown in greenhouses in Samsun province (Black Sea region, Turkey) during the period 2011-2012. The isolates of Rhizoctonia spp. were examined for their cultural characteristics, anastomosis groups and pathogenicity. Of these, $83.8 \%$ were multinucleate Rhizoctonia solani (AG-2, AG-4, AG-5 and AG-6) and 16.2\% were binucleate Rhizoctonia (AG-A, AG-E and AG-F). Sixty five of the isolates belonged to AG-4 which was the most frequent group (61.9\%) in all greenhouses surveyed. Numbers of the isolates belonging to AG-2 (7.6\%), AG-5 (6.7\%) and AG-6 (7.6\%) were 8, 7 and 8, respectively. Seventeen isolates recovered from greenhouses surveyed were identified as binucleate Rhizoctonia AG-A (1.9\%), AG-E (6.7\%) and AG-F (7.6\%). All isolates of Rhizoctonia spp. tested for growth rates grew at temperatures of $10,15,20,25$ and $30^{\circ} \mathrm{C}$, whereas they were completely inhibited at $5^{\circ} \mathrm{C}$. The results of pathogenicity tests showed that the differences in virulence among isolates of Rhizoctonia spp. were statistically significant $(P<0.001)$. The tests on bean seedlings showed that the highest disease severity was caused by AG-4 isolates. The disease severity index (DSI) of the $R$. solani AG-4 isolates ranged from 3.2 to 3.8. In addition, the isolates of three AGs belonging to binucleate Rhizoctonia spp. were generally found to be moderately virulent (DSI 2.0-2.4).
\end{abstract}

KEYWORDS: Anastomosis group. Rhizoctonia spp. Root rot. Vegetables. Virulence.

\section{INTRODUCTION}

Turkey is the fourth largest vegetable producer in the world after China, India and the USA (FAO, 2012). Vegetables are cultivated well in tropical and subtropical regions and also grown in greenhouses or under plastic structure in cooler areas. Turkey's total vegetable production in greenhouses reaches a cultivation area of 647594 da and yields about 6,3 million tonnes. Samsun province, located in the Black Sea region of Turkey, has the largest greenhouse production area in the region with a total cultivation area of 27678 da and production of 130696 tonnes/year (ANONYMOUS, 2015). The most common vegetable species grown in greenhouses in Samsun province are bean (Phaseolus vulgaris), cucumber (Cucumis sativus), eggplant (Solanum melongena), pepper (Capsicum annuum) and tomato (Solanum lycopersicum).

Rhizoctonia species are soilborne fungi with a wide host range, which occur commonly worldwide. There are three main groups of the Rhizoctonia form genus in the anamorphic classification: multinucleate (MN) Rhizoctonia (teleomorphs: Thanatephorus and Waitea), binucleate (BN) Rhizoctonia (teleomorphs:
Ceratobasidium and Tulasnella), and uninucleate (UN) Rhizoctonia (teleomorph: Ceratobasidium) (SHARON et al., 2008). They exist as groups whose cultural characteristics, hosts and virulence differ (ERPER et al., 2006). Rhizoctonia solani Kühn [teleomorph: Thanatephorus cucumeris (Frank) Donk] is a common soilborne fungus. The fungus is considered as a very destructive soilborne plant pathogen, with a broad host range, and causes diseases in a great variety of crops, including agronomical, ornamental and forestry species (GONZALEZ GARCIA et al., 2006; JAISWAL et al., 2014).

Isolates of $R$. solani and BN Rhizoctonia spp. are classified into anastomosis groups (AGs) based on their hyphal anastomosis interactions. So far, 14 AGs of $R$. solani, AG-1 to AG-13, including AG-BI as a subset of AG-2 and 16 AGs of BN Rhizoctonia (AG-A-S) have been reported (SHARON et al., 2008). The classical hyphal fusion method for the identification and classification of Rhizoctonia spp. into AGs has widely been used.

Root rot disease caused by soilborne pathogens cause significant losses on different vegetable plants. $R$. solani is found on bean, cucumber, eggplant, pepper and tomato, which are 
important vegetable crops. In addition, $R$. solani can cause several types of damage, including dampingoff, root rot and web blight on bean (MUYOLO et al., 1993; KARACA et al., 2002; EKEN; DEMIRCI, 2004; ERPER et al., 2011), damping-off and root rot on cucumber (ERPER et al., 2002; HARATIANA et al., 2013; JAISWAL et al., 2014), brown spot on eggplant (SNEH et al., 1991), damping-off, hypocotyl rot and root rot on pepper (KARACA et al., 2002, VELÁSQUEZ; VICTORIANO, 2007; LOPEZ et al., 2009; TUNCER; EKEN, 2013) and damping-off, foot and root rot on tomato (KARACA et al., 2002; MISAWA; KUNINAGA, 2010; SOLANKI et al., 2012).

Five AGs of $R$. solani (AG-1, AG-4, AG-5, AG-6 and AG-7) and 3 AGs of BN Rhizoctonia spp. (AG-A, AG-B and AG-K) had been recovered from plants of bean and their rhizosphere soils in Samsun province (ERPER et al., 2011). Additionally, in Turkey, isolates of AG-1, AG-2 type 1, AG-3, AG-4 and AG-6 of $R$. solani, and the binucleate Rhizoctonia spp. (AG-A, AG-G and AG-K) had been determined on pepper (DEMIRCI; DOKEN, 1995; TUNCER; EKEN, 2013). Similarly, BN Rhizoctonia AG-A, AG-E and AG-F have been reported from bean, cucumber and tomato (SNEH et al., 1991).

Although pathogen-free soilless mix and fungicide seed treatments are used in greenhouse culture, $R$. solani may be introduced on seed, in contaminated potting mix, or by residues in the greenhouse bench (LEWIS; LUMSDEN, 2001). The pathogen may then induce post emergence dampingoff, or after transplanting to a pathogen-infested field, root rot, foliar blight or fruit rot may occur. In the previous studies, researchers reported that Rhizoctonia group fungi were detected on different vegetable crops grown in greenhouses, including cucumber, eggplant, lettuce, tomato and pepper worldwide (LEWIS; LUMSDEN, 2001; ERPER et al., 2002). Mitidieri and Mitidieri (1994) detected $R$. solani on tomato and pepper plants grown in greenhouses in Argentina. In another study, Erper et al., (2002) isolated forty seven isolates of $R$. solani AG-4 and one isolate of BN Rhizoctonia AG-Ba from the cucumber plants with root rot symptoms in greenhouses in Samsun province.

Although Rhizoctonia spp. have been considered as very important pathogens causing high yield losses on different vegetable crops in Turkey, there is no detailed study describing the AGs of Rhizoctonia spp. occurring on some important vegetable crops grown in greenhouses in Samsun province. Thus, the aim of this study was to determine the AGs of the isolates of Rhizoctonia spp. obtained from the five plants (bean, cucumber, eggplant, pepper and tomato) showing symptoms of root rot and from their rhizosphere soils in greenhouses in Samsun province (Black Sea region). We also examined the colony morphology and virulence of the isolates by inoculation tests.

\section{MATERIAL AND METHODS}

\section{Collection and isolation of Rhizoctonia}

The surveys were conducted at 70 locations in eight towns (Alaçam, Atakum, Bafra, Çarşamba, Ondokuzmayıs, Salıpazarı, Tekkeköy and Terme) belonging to Samsun province in the vegetation period of 2011-2012 years. Root samples showing necrotic lesions and rhizosphere soils of five vegetable crops (bean, cucumber, eggplant, pepper and tomato) were randomly collected from greenhouses in the eight towns. Two to three diseased plants were uprooted per greenhouses and necrotic root sections were cut from affected areas. Infected plant tissues were washed under tap water and they were cut into small pieces, placed in $1 \%$ $\mathrm{NaOCl}$ for 2 min, rinsed twice with sterile-distilled water (SDW) and blotted dry on sterile paper towels. Small pieces of discoloured root tissues were placed on $2 \%$ water agar (WA) amended with $3 \mathrm{~mL} \mathrm{10 \%} \mathrm{lactic} \mathrm{acid} \mathrm{in} \mathrm{9-cm-diameter} \mathrm{Petri} \mathrm{plates}$ (ERPER et al., 2011). After incubation for two days at $25^{\circ} \mathrm{C}$ in the dark, hyphae were examined under a light microscope (100X), and fungal colonies possessing the general characteristics of Rhizoctonia spp. were transferred to the plates containing potato dextrose agar (PDA) (Oxoid Ltd, UK). In addition, soil samples were placed in two parallel small plastic pots and watered to saturation with SDW. Sterile oat stem pieces of $2-3 \mathrm{~cm}$ long were embedded into soil and pots were kept at room temperature for 5 days under the plastic covering. Oat stem pieces were then washed with tap water, surface-disinfected and placed on acidified WA plates. Similarly, after incubation for two days at $25^{\circ} \mathrm{C}$ in the dark, hyphae were examined, and fungal colonies possessing the general characteristics of Rhizoctonia spp. were transferred to the plates containing PDA. One set of isolates was kept on PDA slants at $4^{\circ} \mathrm{C}$ in the dark and another set was stored as colonized sterile oat seeds in test tubes under similar conditions.

\section{Staining of nuclei}

To distinguish isolates of MN R. solani and BN Rhizoctonia spp., they were transferred to PDA and incubated at $25^{\circ} \mathrm{C}$ in the dark. Developing young hyphae of the isolates were stained with 
Safranin $\mathrm{O}$ and $3 \% \mathrm{KOH}$ and the number of nuclei were observed for at least 20 different cells, by using an Olympus CX31 compound microscope (Olympus America Inc., USA) at 400X magnification (MISAWA; KUNINAGA, 2010).

\section{Hyphal anastomosis}

Anastomosis groups were determined by pairing the isolates with known AG tester isolates. The isolates of Rhizoctonia and testers were transferred to PDA, and activated at $25^{\circ} \mathrm{C}$. Sterile coverslips were dipped in PDA containing $0.5 \%$ agar and placed on $1.5 \%$ WA plates. Five millimeter diameter agar discs of the isolates cut from the margins of the growing colonies were placed $1 \mathrm{~cm}$ apart on opposite sides of the coverslips on WA. After $24-48 \mathrm{~h}$ incubation at $25^{\circ} \mathrm{C}$, hyphal anastomosis was determined by transferring the coverslip onto a microscope slide and staining with Safranin $\mathrm{O}$ and $3 \% \mathrm{KOH}$ using the Olympus CX31 compound microscope at $400 \mathrm{X}$ magnification (ERPER et al., 2006). All tester isolates used in this study were provided by Dr. Erkol Demirci, Karadeniz Technical University.

\section{Morphological characterization of Rhizoctonia isolates}

The colour of colony and size, shape and colour of sclerotia of the twenty-two isolates of randomly selected Rhizoctonia spp., representing all anastomosis groups were evaluated for colony morphology (Table 2). The isolates were grown on PDA in the dark at $25^{\circ} \mathrm{C}$ for 3 weeks. The size, shape and colour of sclerotia and colour of colony on the reverse of the plates of the isolates grown were described using the colour chart of the Royal Horticultural Society of London (ERPER et al., 2013). Five replicates were used per isolate and the experiment was conducted once.

\section{Determination of the number of nuclei and hyphal diameter}

The twenty-two isolates of Rhizoctonia spp. were grown on PDA plates at $25^{\circ} \mathrm{C}$ in the dark (Table 2). Sterile coverslips were dipped in PDA containing $0.5 \%$ agar and placed on $1.5 \%$ WA plates. Five $\mathrm{mm}$ diameter agar disks from the edge of Rhizoctonia colonies growing on PDA were placed $1 \mathrm{~cm}$ near the coverslips on WA, and coverslips were transferred onto microscope slides after $24-48 \mathrm{~h}$ incubation at $25^{\circ} \mathrm{C}$. The number of nuclei was counted after staining with one drop of Safranin $\mathrm{O}$ solution and one drop of $3 \% \mathrm{KOH}$. Nuclei were counted in 20 hyphal cells of actively growing cultures per isolate. Besides, hyphal diameter was determined for each isolate by measuring 20 cells at right angles to the longitudinal cell wall by using the Olympus CX31 compound microscope at 400X magnification (ERPER et al., 2006).

\section{Radial growth of isolates of Rhizoctonia}

Seven isolates of randomly selected Rhizoctonia spp., representing each anastomosis group (Figure 1) were tested for growth rate at seven temperatures: $5,10,15,20,25,30$ and $35^{\circ} \mathrm{C}$. Five $\mathrm{mm}$ diameter agar disks from the edge of 4day-old colonies growing on PDA at $25^{\circ} \mathrm{C}$ were placed in the centre of 9-cm-diameter Petri plates containing PDA, which were then incubated in the dark at seven temperatures above (ERPER et al., 2006). The radius of each colony was measured at two different points after 24 and $48 \mathrm{~h}$. Radial growth rates in millimeters per day were calculated (ERPER et al., 2013). Five replicates were used for each isolate at each temperature. The experiment was conducted once.

\section{Pathogenicity assays}

The pathogenicity test was performed using in vitro bioassays (agar-plate) and in vivo experiments. The pathogenicity and level of virulence of 105 isolates of Rhizoctonia spp. belonged to seven AGs (Table 1) was determined on bean cv. Gina seedlings. For in vitro experiments, an agar plate assay was used the method of Tuncer and Eken (2013). Isolates were transferred to PDA and incubated at $25^{\circ} \mathrm{C}$ for $2-3$ days. Five $\mathrm{mm}$ diameter agar plugs with mycelium from the growing edge of the cultures were then transferred to 9-cm-diameter Petri plates including $2 \%$ water agar and incubated under same conditions for two and more days. Bean seeds were surface disinfested in $1 \% \mathrm{NaOCl}$ for 3 minutes, rinsed with steriledistilled water and blotted dry. Five seeds were placed on the plates adjacent to the margin of the growing mycelia. After 10 days incubation at $25^{\circ} \mathrm{C}$, disease severity index (DSI) was assessed by evaluating seedling/root symptoms using the following scale modified from Muyolo et al. (1993): $0=$ healthy seedling; $1=$ very little superficial lesions on the roots or on the hypocotyls; $2=$ deep and large lesions on the roots or on the hypocotyl; 3 $=$ severe root rot, lesions surrounding hypocotyl, partially restricted root length and $4=$ complete root rot.

According to in vitro pathogenicity test results, twenty-one isolates belonging to different AGs that showed the highest virulence in vitro were chosen for in vivo experiments. Pathogenicity of the 
selected isolates was determined on bean (cv. Gina) seedlings in vivo. Inoculum was prepared on the moistened sterile oat grains in tests tubes, which were autoclaved twice at $24 \mathrm{~h}$ intervals, inoculated with plugs of mycelium from cultures of the isolates grown on PDA and incubated at $25^{\circ} \mathrm{C}$ for 21 days.

For seedling tests, two bean seeds were planted in 16-cm-diam plastic pots $(1 \mathrm{~L})$ containing sterilized mixture of sandy loam soil:composted manure:washed sand $(2: 2: 1, \mathrm{v} / \mathrm{v} / \mathrm{v})$, in a greenhouse at $17-25^{\circ} \mathrm{C}$. Two-week-old seedlings were inoculated by gently removing the soil mixture from one side of the stem, placing 15 colonized oat grains in contact with each seedling and covering the inoculum with the soil mixture (ERPER et al., 2011). In control treatments, sterile oat grains were used. Pathogenicity tests were carried out in a completely randomized design with five replicates for each isolate. Twenty-one days after inoculation, plants were gently uprooted and washed free of soil. DSI was assessed by evaluating seedling/root symptoms using the same scale used in vitro bioassays. In addition, plant height, shoot and root dry weights and root length were also recorded for each plant. Symptomatic roots were aseptically plated on PDA to complete Koch's postulates. The experiments were conducted once.

\section{Statistical analysis}

To analyze the data of in vivo test, Kolmogorov-Smirnov one sample test was performed to examine the normality, pathogenicity test results showed that all data have not distributed normally. Levene variance homogenity test was performed to obtain the information about homoscedasticity, and according to the results, data for disease severity and plant growth data (plant height, shoot and root dry weights and root length) had not similar variances. Then, non-parametric permutation tests were applied to the data. To compare the means, posterior pairwise permutation tests were used. For disease severity and plant growth data 999999 permutation was done. Data analyses were utilized with software NPMANOVA written by Anderson (ONDER, 2007).

\section{RESULTS}

\section{groups \\ Rhizoctonia species and anastomosis}

A total of one hundred and five isolates of Rhizoctonia belonging to 7 AGs were obtained from their diseased roots and rhizosphere soils of bean, cucumber, eggplant, pepper and tomato plants grown in greenhouses in Samsun. Out of those, 88 isolates were identified as multinucleate $R$. solani $(83.8 \%)$ and 17 isolates as binucleate Rhizoctonia $(16.2 \%)$ by nucleus staining. Four anastomosis groups were determined among the multinucleate isolates. Sixty-five of the isolates belonged to AG-4 which was the most frequent group $(61.9 \%)$ in all greenhouses surveyed. Numbers of the isolates belonging to AG-2 (7.6\%), AG-5 (6.7\%) and AG-6 (7.6\%) were 8,7 and 8 , respectively. Seventeen isolates recovered from the greenhouses surveyed were identified as binucleate Rhizoctonia AG-A (1.9\%), AG-E (6.7\%) and AG-F (7.6\%). As a result of the study, of 37 cucumber isolates, 19 were obtained from root samples and the remaining 18 were from rhizosphere soils. Numbers of the isolates of obtained from eggplant and pepper were less than the number of isolates obtained from three other plants. Additionally, a result of distribution of isolates of Rhizoctonia spp. belonging to 7 AGs obtained from the roots of five plants and from their rhizosphere soils were given in Table 1 .

\section{Cultural characteristics}

\section{Colony morphology}

After 3 weeks of incubation in the dark at $25^{\circ} \mathrm{C}$, all colonies of $R$. solani $\mathrm{AG}-2$ and $\mathrm{AG}-4$ became brown, whereas AG-5 and AG-6 colonies became grey-brown with age. Additionally, the isolates belonging to four AGs of $R$. solani also produced sclerotia on PDA, which were variable in size and often aggregated into compound sclerotia. For instance, the diameters of sclerotia of isolates of AG-4 varied from 0.3 to $1.10 \mathrm{~mm}$. The sclerotia were generally grey-brown coloured at first, then became dark brown with age. The isolates of $\mathrm{BN}$ Rhizoctonia AG-A had white-orange mycelia and formed superficial sclerotia (ranged from 0.1 to 0.35 $\mathrm{mm})$ that were scattered on the plate surface. Additionally, the colonies of BN Rhizoctonia AG-E became grey-brown, whereas AG-F colonies became greyed-yellow with age. Nuclear numbers, hyphae and sclerotia diameters of the isolates of Rhizoctonia obtained from five plants were given in Table 2. 
Table 1. Anastomosis groups (AGs) and isolate numbers of Rhizoctonia spp. recovered from roots and rhizosphere soils of bean, cucumber, eggplant, pepper and tomato plants grown in greenhouses in Samsun province.

\begin{tabular}{|c|c|c|c|c|c|c|c|c|c|c|c|}
\hline \multirow{3}{*}{$\begin{array}{c}\text { Species/ } \\
\text { Anastomosis Groups } \\
\text { (AGs) }\end{array}$} & \multicolumn{10}{|c|}{ Origin of the isolates } & \multirow{3}{*}{ Total } \\
\hline & \multicolumn{2}{|c|}{ Cucumber } & \multicolumn{2}{|c|}{ Bean } & \multicolumn{2}{|c|}{ Tomato } & \multicolumn{2}{|c|}{ Eggplant } & \multicolumn{2}{|c|}{ Pepper } & \\
\hline & Root & Soil & Root & Soil & Root & Soil & Root & Soil & Root & Soil & \\
\hline \multicolumn{12}{|l|}{ Rhizoctonia solani } \\
\hline AG-2 & - & - & - & - & 1 & 7 & - & - & - & - & 8 \\
\hline AG-4 & 15 & 11 & 10 & 8 & 9 & 3 & 2 & 3 & 2 & 2 & 65 \\
\hline AG-5 & 2 & - & - & 2 & 1 & - & - & - & - & 2 & 7 \\
\hline AG-6 & 2 & 1 & 2 & - & 3 & - & - & - & - & - & 8 \\
\hline \multicolumn{12}{|l|}{ Binucleate } \\
\hline \multicolumn{12}{|l|}{ Rhizoctonia } \\
\hline AG-A & - & 2 & - & - & - & - & - & - & - & - & 2 \\
\hline AG-E & - & 1 & 2 & 2 & - & - & - & - & - & 3 & 8 \\
\hline AG-F & - & 2 & - & 5 & - & - & - & - & - & - & 7 \\
\hline Total & 19 & 17 & 14 & 17 & 14 & 10 & 2 & 3 & 2 & 7 & 105 \\
\hline
\end{tabular}

Table 2. Colour of colony, number of nuclei in mature hyphal cells, hyphal diameter and diameter of sclerotia of isolates of Rhizoctonia spp. obtained from roots and rhizosphere soils of bean, cucumber, eggplant, pepper and tomato, grown on potato dextrose agar (PDA).

\begin{tabular}{|c|c|c|c|c|c|}
\hline $\begin{array}{l}\text { Species/Anastomosis } \\
\text { groups (AGs) }\end{array}$ & $\begin{array}{l}\text { Number of } \\
\text { isolates } \\
\text { studied }\end{array}$ & $\begin{array}{l}\text { Colony } \\
\text { colour }^{\mathrm{a}}\end{array}$ & $\begin{array}{c}\text { Number of } \\
\text { nuclei per } \\
\text { cell }^{\mathrm{b}}\end{array}$ & $\begin{array}{c}\text { Hyphal diameter }^{b} \\
(\mu \mathrm{m})\end{array}$ & $\begin{array}{l}\text { Sclerotia diameter } \\
(\mathrm{mm})\end{array}$ \\
\hline \multicolumn{6}{|l|}{ Rhizoctonia solani } \\
\hline AG-2 & 3 & Brown & (3-) $5.5(-8)^{\mathrm{c}}$ & $(4.3-) 6.9(-9.5)$ & $(0.15-) 0.60(-1.05)$ \\
\hline AG-4 & 5 & Brown & (2-) $5.5(-9)$ & (4.5-) $7.0(-9.5)$ & $(0.30-) 0.70(-1.10)$ \\
\hline AG-5 & 3 & Grey-brown & $(3-) 6.0(-9)$ & (4.9-) $7.7(-10.5)$ & $(0.28-) 0.67(-1.07)$ \\
\hline AG-6 & 3 & Grey-brown & (3-) $6.5(-10)$ & $(4.7-) 6.8(-8.9)$ & $(0.25-) 0.68(-1.12)$ \\
\hline \multicolumn{6}{|l|}{ BN Rhizoctonia } \\
\hline AG-A & 2 & White-orange & (1-) $1.7(-2)$ & $(3.0-) 3.8(-4.5)$ & $(0.10-) 0.22(-0.35)$ \\
\hline AG-E & 3 & Grey-brown & (1-) $1.5(-2)$ & $(3.4-) 4.7(-6.0)$ & $(0.15-) 0.40(-0.65)$ \\
\hline AG-F & 3 & Greyed-yellow & $(1-) 1.5(-2)$ & $(3.2-) 4.7(-6.1)$ & $(0.10-) 0.19(-0.28)$ \\
\hline
\end{tabular}

${ }^{a}$ - colony colours were determined on PDA by using the color chart of the Royal Horticultural Society of London; ${ }^{b}-$ twenty observations per isolate; ${ }^{\mathrm{c}}-$ mean and range values

\section{Radial growth}

All isolates of Rhizoctonia spp. tested for growth rates grew at temperatures of 10, 15, 20, 25 and $30{ }^{\circ} \mathrm{C}$, whereas they were completely inhibited at $5^{\circ} \mathrm{C}$. However, four isolates (Rs-7, Rs-70, Rs-86 and R-40) grew at $35^{\circ} \mathrm{C}$ on PDA. Growth rates of the isolates of $R$. solani AG-2 (Rs-7), AG-4 (Rs-70) and AG-5 (Rs-86), and isolates of BN Rhizoctonia AG-A (R-40), AG-E (R-23) and AG-F (R-15) increased as temperature increased up to $25^{\circ} \mathrm{C}$, and decreased above this temperature. However, the growth of AG-6 isolate (Rs-64) increased up to $30^{\circ} \mathrm{C}$, then decreased (Figure 1).

\section{Pathogenicity of the Rhizoctonia isolates}

As a result of the pathogenicity test, it was found that the differences among the pathogenicity and levels of virulence of isolates of MN $R$. solani and BN Rhizoctonia were statistically significant $(P$ $<0.001)$. The tests on bean seedlings showed that the highest disease severity was caused by AG-4 isolates. The DSI of the $R$. solani AG-4 isolates ranged from 3.2 to 3.8. Symptoms developed by one week after inoculation in some treatments, and were damping-off, namely rotting of stem and root tissues at and below the soil surface. However, nine isolates belonging to $R$. solani AG-2, 5 and 6 were found to be moderately virulent (DSI ranged from 2.4 to 2.8), with the exception of Rs-42 isolate belonging to AG-2. 


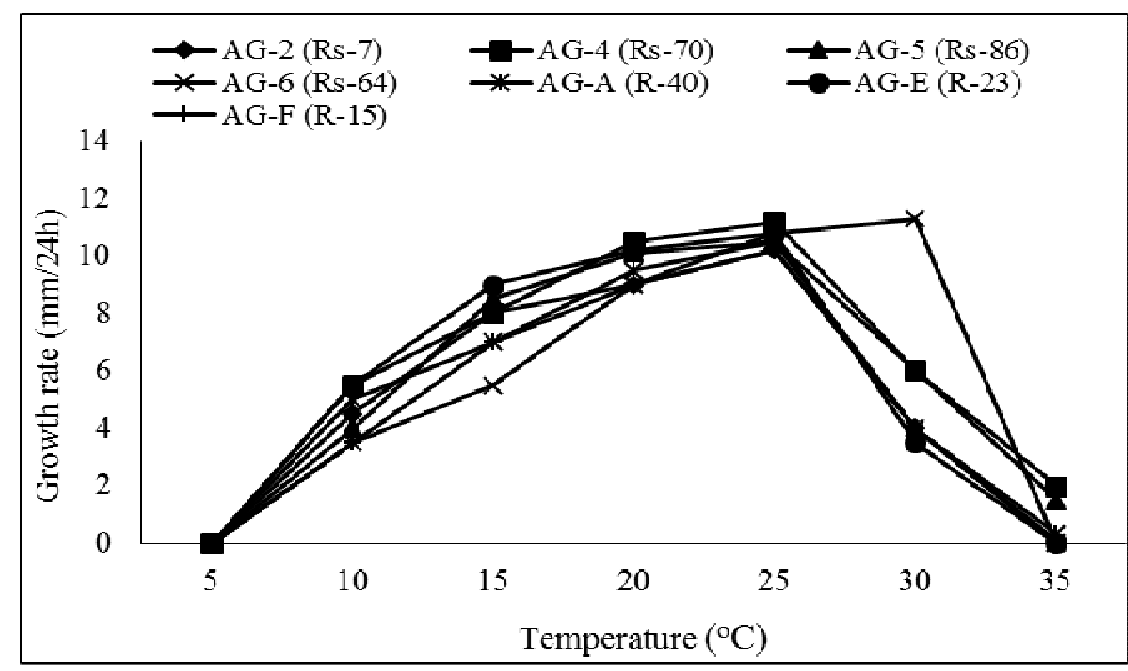

Figure 1. Radial growth rates of Rhizoctonia solani AG-2 (Rs-7), AG-4 (Rs-70), AG-5 (Rs-86) and AG-6 (Rs64), and BN Rhizoctonia AG-A (R-40), AG-E (R-23) and AG-F (R-15) isolates at 5-35 ${ }^{\circ}$.

The four isolates of three AGs belonging to binucleate Rhizoctonia spp. were found to be moderately virulent (DSI 2.0-2.4). However, the virulence of isolates of BN Rhizoctonia AG-E (R23) and AG-F (R-8) were found to be low, namely, DSI of these isolates were 1.8 and 1.6, respectively. In addition, most of the isolates of Rhizoctonia spp. reduced plant growth parameters (plant height, shoot and root dry weights and root length) when compared to the uninoculated controls (Table 3). All the isolates used in the pathogenicity test were reisolated from the affected plants on PDA as described above, confirming Koch's postulates.

Table 3. Pathogenicity of isolates of Rhizoctonia obtained from the roots and rhizosphere soils of bean, cucumber, eggplant, pepper and tomato plants grown in greenhouses on seedlings of the cv. Gina twenty-one days after inoculation.

\begin{tabular}{|c|c|c|c|c|c|c|}
\hline \multirow{2}{*}{$\begin{array}{c}\text { Species/ } \\
\text { Anastomosis Groups (AGs) }\end{array}$} & \multirow{2}{*}{$\begin{array}{l}\text { Isolate } \\
\text { number }\end{array}$} & \multicolumn{3}{|l|}{ Root } & \multirow{2}{*}{$\begin{array}{l}\text { Shoot dry } \\
\text { weight }(\mathrm{g})\end{array}$} & \multirow{2}{*}{$\begin{array}{l}\text { Plant height } \\
\qquad(\mathrm{cm})\end{array}$} \\
\hline & & $\begin{array}{c}\text { Disease } \\
\text { severity } \\
\text { index }^{\mathrm{a}}\end{array}$ & $\begin{array}{l}\text { Dry weight } \\
\text { (g) }\end{array}$ & $\begin{array}{l}\text { Lenght } \\
(\mathrm{cm})\end{array}$ & & \\
\hline \multirow[t]{3}{*}{$\begin{array}{l}\text { Rhizoctonia solani } \\
\text { AG-2 }\end{array}$} & Rs-7 & $2.4^{\mathrm{b}} \pm 0.24^{\mathrm{c}} \mathrm{c}-\mathrm{f}^{\mathrm{d}}$ & $\begin{array}{c}0.026 \pm 0.01 \\
b\end{array}$ & $\begin{array}{c}3.50 \pm 0.50 \\
\mathrm{de}\end{array}$ & $\begin{array}{c}0.40 \pm 0.06 \\
\mathrm{~g}\end{array}$ & $21.30 \pm 1.81 \mathrm{~cd}$ \\
\hline & Rs-42 & $1.8 \pm 0.37$ ef & $\begin{array}{c}0.018 \pm 0.00 \\
\text { bc }\end{array}$ & $\begin{array}{c}6.00 \pm 0.94 \\
\text { bc }\end{array}$ & $\begin{array}{l}0.48 \pm 0.08 \\
\text { cd }\end{array}$ & $19.70 \pm 1.81 \mathrm{cde}$ \\
\hline & Rs-58 & $2.4 \pm 0.24 \mathrm{c}-\mathrm{f}$ & $\begin{array}{c}0.018 \pm 0.00 \\
\mathrm{bc}\end{array}$ & $\begin{array}{l}4.30 \pm 0.83 \\
\quad \text { cde }\end{array}$ & $\begin{array}{l}0.25 \pm 0.03 \\
\text { ghi }\end{array}$ & $16.50 \pm 1.24 \mathrm{ef}$ \\
\hline \multirow[t]{6}{*}{ AG-4 } & Rs-10 & $3.8 \pm 0.20 \mathrm{a}$ & $\begin{array}{c}0.010 \pm 0.00 \\
\mathrm{c}\end{array}$ & $\begin{array}{c}0.46 \pm 0.26 \\
\mathrm{f}\end{array}$ & $0.15 \pm 0.02 \mathrm{ij}$ & $7.50 \pm 0.79 \mathrm{gf}$ \\
\hline & Rs-44 & $3.6 \pm 0.24 \mathrm{ab}$ & $\begin{array}{c}0.010 \pm 0.00 \\
\mathrm{c}\end{array}$ & $\begin{array}{c}0.42 \pm 0.16 \\
\mathrm{f}\end{array}$ & $\begin{array}{l}0.16 \pm 0.02 \\
\text { hij }\end{array}$ & $9.70 \pm 0.98 \mathrm{~g}$ \\
\hline & Rs-57 & $3.8 \pm 0.20 \mathrm{a}$ & $\begin{array}{c}0.010 \pm 0.00 \\
\mathrm{c}\end{array}$ & $\begin{array}{c}0.94 \pm 0.26 \\
\mathrm{f}\end{array}$ & $0.02 \pm 0.00 \mathrm{j}$ & $4.50 \pm 1.02 \mathrm{~h}$ \\
\hline & Rs-70 & $3.6 \pm 0.24 \mathrm{ab}$ & $\begin{array}{c}0.010 \pm 0.00 \\
\mathrm{c}\end{array}$ & $\begin{array}{c}0.62 \pm 0.27 \\
\mathrm{f}\end{array}$ & $0.12 \pm 0.03 \mathrm{ij}$ & $5.90 \pm 0.75 \mathrm{gh}$ \\
\hline & Rs-80 & $3.2 \pm 0.37 \mathrm{abc}$ & $\begin{array}{c}0.010 \pm 0.00 \\
\mathrm{c}\end{array}$ & $\begin{array}{c}0.94 \pm 0.26 \\
\mathrm{f}\end{array}$ & $0.05 \pm 0.01 \mathrm{j}$ & $5.80 \pm 0.68 \mathrm{gh}$ \\
\hline & Rs-94 & $3.6 \pm 0.24 \mathrm{ab}$ & $\begin{array}{c}0.010 \pm 0.00 \\
\mathrm{c}\end{array}$ & $\begin{array}{c}0.82 \pm 0.39 \\
\mathrm{f}\end{array}$ & $0.14 \pm 0.02 \mathrm{ij}$ & $8.20 \pm 1.66 \mathrm{gh}$ \\
\hline AG-5 & Rs-9 & $2.4 \pm 0.24 \mathrm{c}-\mathrm{f}$ & $\begin{array}{c}0.020 \pm 0.00 \\
\mathrm{bc}\end{array}$ & $\begin{array}{c}3.10 \pm 0.51 \\
\mathrm{e}\end{array}$ & $\begin{array}{c}0.45 \pm 0.04 \mathrm{c}- \\
\mathrm{f}\end{array}$ & $\begin{array}{l}19.80 \pm 0.98 \\
\text { cde }\end{array}$ \\
\hline
\end{tabular}


Characterization and pathogenicity...

YILDIRIM, E.; Ismail ERPER, I.

\begin{tabular}{|c|c|c|c|c|c|c|}
\hline & Rs-26 & $2.4 \pm 0.24 \mathrm{c}-\mathrm{f}$ & $\begin{array}{c}0.020 \pm 0.00 \\
\text { bc }\end{array}$ & $\begin{array}{c}5.1 \pm 1.10 \\
\text { b-e }\end{array}$ & $\begin{array}{c}0.58 \pm 0.09 \\
b c\end{array}$ & $21.70 \pm 1.45 \mathrm{c}$ \\
\hline & Rs-86 & $2.8 \pm 0.20 \mathrm{bcd}$ & $0.020 \pm 0.00$ & $6.50 \pm 0.63$ & $0.48 \pm 0.07$ & $21.40 \pm 1.73 \mathrm{bc}$ \\
\hline \multirow[t]{3}{*}{ AG-6 } & Rs-36 & $2.4 \pm 0.24 \mathrm{c}-\mathrm{f}$ & $0.014 \pm 0.00$ & $5.10 \pm 0.76$ & $0.28 \pm 0.09$ e- & $15.10 \pm 1.79 \mathrm{f}$ \\
\hline & Rs-64 & $2.4 \pm 0.24 \mathrm{c}-\mathrm{f}$ & $\begin{array}{c}0.018 \pm 0.00 \\
\mathrm{bc}\end{array}$ & $\begin{array}{c}3.40 \pm 0.43 \\
\text { de }\end{array}$ & $\begin{array}{c}0.38 \pm 0.08 \mathrm{~d}- \\
\mathrm{g}\end{array}$ & $\begin{array}{c}20.00 \pm 0.61 \\
\text { cde }\end{array}$ \\
\hline & Rs-93 & $2.6 \pm 0.24 \mathrm{cde}$ & $\begin{array}{c}0.018 \pm 0.00 \\
\text { bc }\end{array}$ & $\begin{array}{c}5.60 \pm 0.58 \\
\text { bc }\end{array}$ & $\begin{array}{c}0.43 \pm 0.08 \mathrm{c}- \\
\mathrm{g}\end{array}$ & $18.80 \pm 1.54 \mathrm{c}-\mathrm{f}$ \\
\hline \multicolumn{7}{|c|}{ inucleate Rhizoctonia } \\
\hline \multirow{2}{*}{ AG-A } & $\mathrm{R}-40$ & $2.4 \pm 0.24 \mathrm{c}-\mathrm{f}$ & $0.018 \pm 0.00$ & $5.60 \pm 0.29$ & $0.68 \pm 0.07 \mathrm{~b}$ & $27.20 \pm 1.27 \mathrm{~b}$ \\
\hline & $\mathrm{R}-41$ & $2.4 \pm 0.24 \mathrm{c}-\mathrm{f}$ & $\begin{array}{c}\mathrm{bc} \\
0.014 \pm 0.00 \\
\mathrm{c}\end{array}$ & $\begin{array}{c}\mathrm{bc} \\
4.80 \pm 0.51 \\
\mathrm{~b}-\mathrm{e}\end{array}$ & $\begin{array}{l}0.46 \pm 0.08 \\
\text { cde }\end{array}$ & $22.60 \pm 0.70 \mathrm{c}$ \\
\hline \multirow[t]{2}{*}{ AG-E } & $\mathrm{R}-23$ & $1.8 \pm 0.37$ ef & $\begin{array}{c}0.018 \pm 0.00 \\
\text { bc }\end{array}$ & $\begin{array}{c}5.40 \pm 0.53 \\
\text { bcd }\end{array}$ & $\begin{array}{c}0.38 \pm 0.05 \mathrm{~d}- \\
\mathrm{g}\end{array}$ & $21.80 \pm 0.51 \mathrm{c}$ \\
\hline & R-98 & $2.0 \pm 0.32 \mathrm{def}$ & $\begin{array}{c}0.016 \pm 0.00 \\
b c\end{array}$ & $\begin{array}{c}4.70 \pm 0.25 \\
b-e\end{array}$ & $\begin{array}{c}0.39 \pm 0.04 \mathrm{~d}- \\
\mathrm{g}\end{array}$ & $\begin{array}{c}20.10 \pm 0.83 \\
\text { cde }\end{array}$ \\
\hline \multirow[t]{3}{*}{ AG-F } & $\mathrm{R}-8$ & $1.6 \pm 0.24 \mathrm{f}$ & $\begin{array}{c}0.014 \pm 0.00 \\
\mathrm{c}\end{array}$ & $\begin{array}{l}4.00 \pm 0.35 \\
\text { cde }\end{array}$ & $\begin{array}{c}0.32 \pm 0.01 \mathrm{~d}- \\
\mathrm{h}\end{array}$ & $\begin{array}{l}19.70 \pm 0.98 \\
\text { cde }\end{array}$ \\
\hline & $\mathrm{R}-82$ & $2.0 \pm 0.32 \mathrm{def}$ & $\begin{array}{c}0.016 \pm 0.00 \\
\text { bc }\end{array}$ & $\begin{array}{l}4.20 \pm 0.25 \\
\text { cde }\end{array}$ & $\begin{array}{c}0.27 \pm 0.02 \mathrm{f}- \\
\mathrm{i}\end{array}$ & $\begin{array}{c}17.40 \pm 0.62 \\
\operatorname{def}\end{array}$ \\
\hline & Control & $0.0 \pm 0.0 \mathrm{~g}$ & $\begin{array}{c}0.068 \pm 0.01 \\
\mathrm{a}\end{array}$ & $\begin{array}{c}24.30 \pm 1.47 \\
\mathrm{a}\end{array}$ & $0.91 \pm 0.05 \mathrm{a}$ & $47.60 \pm 2.38 \mathrm{a}$ \\
\hline $\mathrm{P}$ value & & $<0.001$ & $<0.001$ & $<0.001$ & $<0.001$ & $<0.001$ \\
\hline
\end{tabular}

a - Roots symptoms were evaluated on the following scale: $0=$ healthy seedling, $1=$ very little superficial lesions on roots or on the hypocotyls, 2 = deep and large lesions on the roots or on the hypocotyl, 3 = severe root rot, lesions surrounding hypocotyl, partially restricted root length and $4=$ complete root rot. $^{\mathrm{b}}$ - values represent the mean of five replications for each isolate; ${ }^{\mathrm{c}}-$ mean values followed by standard error of the mean; ${ }^{\mathrm{d}}$ - means in a column followed by the same letter are not significantly different according to Pairwise permutation test $(P<0.001)$.

\section{DISCUSSION}

This is the first detailed study on various isolates of Rhizoctonia spp. belonging to different AGs obtained from diseased roots and rhizosphere soils of bean, cucumber, eggplant, pepper and tomato plants grown in greenhouses in Samsun province, which has the largest greenhouse production area of Black Sea region. Of all the Rhizoctonia isolates obtained from the five plants, $83.8 \%$ were $R$. solani (AG-2, AG-4, AG-5 and AG6 ), and $16.2 \%$ were binucleate Rhizoctonia (AG-A, AG-E and AG-F).

In the previous studies, researchers reported that $R$. solani and BN Rhizoctonia spp. were detected on different vegetable crops, including bean, cucumber, eggplant, melon, onion, pepper, pumpkin, tomato, watermelon and winter squash worldwide (SNEH et al., 1991; ERPER et al., 2002; 2006; 2011; 2015; MIRMAJLESSI et al., 2012; MISAWA; KUNINAGA, 2010).

Karaca et al. (2002) isolated 229 isolates belonging to $R$. solani AG-2-2, AG-4 and AG-5 from roots and rhizosphere soils of the bean plants in Samsun province. In a similar study, a total of 434 isolates of Rhizoctonia spp. belonging to 9 anastomosis groups (MN $R$. solani AG-1, AG-4, AG-5, AG-6, AG-7, and BN Rhizoctonia AG-A, AG-B, AG-E and AG-K) were obtained from the roots and rhizosphere soils of bean and soybean plants grown in Samsun province, and AG-4 was found to be the most common group on bean and soybean plants (ERPER et al., 2011). In another study, isolates of $R$. solani AG-4 were recovered from infected winter squash plants grown in the Black Sea region (ERPER et al., 2015). However, in Turkey, isolates of AG-1, AG-2 type 1, AG-3, AG4, AG-5, AG-6, AG-9, AG-10 and AG-11 of $R$. solani and AG-A, AG-E, AG-F, AG-G, AG-I and AG-K of BN Rhizoctonia were previously detected on bean and pepper plants in different regions of Turkey (DEMIRCI; DOKEN, 1995; EKEN; DEMIRCI, 2004; TUNCER; EKEN, 2013). In addition, Misawa and Kuninaga (2010) identified foot rot caused by $R$. solani AG-2-1 and AG-3 on mature tomato plants in Hokkaido, Japan.

Similarly, other researchers reported that Rhizoctonia group fungi were detected on 
cucumber, eggplant, lettuce, tomato and pepper grown in greenhouses worldwide (MITIDIERI; MITIDIERI, 1994; LEWIS; LUMSDEN, 2001; ERPER et al., 2002). Mitidieri and Mitidieri (1994) detected $R$. solani on tomato and pepper plants grown in greenhouses in Argentina. In the present study, 65 of the isolates belonged to $R$. solani AG-4 which was the most frequent group $(61.9 \%)$ in all greenhouses surveyed. Similar findings were reported by previous researchers. Erper et al. (2002) found that a total of 48 Rhizoctonia isolates were recovered from the roots of cucumber plants, which were with root rot symptoms in greenhouses in Samsun. As a result of the study, $R$. solani AG-4 was found as the most prevalent anastomosis group (97.9\%). Additionally, Tuncer and Eken (2013) found that more than three quarters of the $81 R$. solani isolates obtained from peppers grown in Erzincan province, Turkey belonged to AG-4. Alike, the most common occurrence of $R$. solani AG-4 isolates on cucumber, pepper and snap bean plants has also been reported from other countries by several workers (MIRMAJLESSI et al., 2012; HARATIANA et al., 2013).

Colony characteristics of isolates belonging to $R$. solani AG-4 were found to be similar to those of other studies (SNEH et al., 1991; ERPER et al., 2006). After 3 weeks of incubation, all colonies of $R$. solani AG-4 became brown colour, and their sclerotia were generally grey-brown coloured at first, then became dark brown with age. The results are compatible with those of Erper et al. (2006), who reported that AG-4 isolates produced brown coloured colonies on PDA after 2 weeks incubation and their sclerotia were approximately $0.4 \mathrm{~mm}$ diameter, light brown, becoming dark brown with age. We found that the optimum growth temperature of isolates of $R$. solani AG-2 (Rs-7), AG-4 (Rs-70) and AG-5 (Rs-86), and isolates of BN Rhizoctonia AG-A (R-40), AG-E (R-23) and AG-F (R-15) was $25^{\circ} \mathrm{C}$. The growth rates of the isolates decreased above this temperature. The temperature of $25^{\circ} \mathrm{C}$ has previously been reported to be optimal for $R$. solani AG-4, BN Rhizoctonia AG-A and AG-K isolates obtained from different plants (DEMIRCI, 1998; ERPER et al., 2006; MISAWA; KUNINAGA, 2010). Demirci (1998) found that $R$. solani AG-4 (WH1) and AG-K (BO2) isolates from wheat and barley grew best at $25^{\circ} \mathrm{C}$. In another study, optimum growth of $R$. solani AG-4 isolates (TM-40 and TY-19) obtained from onion were between $25-30^{\circ} \mathrm{C}$ (ERPER et al., 2006). Likewise, Misawa and Kuninaga (2010) found that $R$. solani
AG-2-1 (N1 and N2) isolates obtained from tomato grew optimum at $25^{\circ} \mathrm{C}$, and their growth rate at this temperature was $15.7 \mathrm{~mm} / 24 \mathrm{~h}$. On the contrary, in the present study, the isolate of AG-6 (Rs-64) grew best at $30^{\circ} \mathrm{C}$ (Table 2 ).

In our study, among all the isolates of Rhizoctonia spp. examined, the isolates of $R$. solani AG-4 had the highest virulence (DSI 3.2-3.8) on the bean plants. In addition, BN Rhizoctonia AG-A, AG-E and AG-F isolates were moderately virulent (DSI 2.0-2.4), whereas the virulence of R-23 (AGE) and R-8 (AG-F) isolates belonging to BN Rhizoctonia were low. The results of previous studies are in agreement with the finding that isolates of AG-4 were more aggressive than those of other BN Rhizoctonia anastomosis groups on different host plants (ERPER et al., 2002; 2011). Erper et al. (2006) found that the isolates of $R$. solani AG-4 had the highest virulence on onion plants, whereas the isolate TA-18 of $\mathrm{BN}$ Rhizoctonia AG-B had low virulence.

\section{CONCLUSIONS}

The results have showed that root rot on the five plants is predominantly caused by $R$. solani AG-4 isolates, and that the virulence of the isolates of other AGs belonging to $R$. solani and $\mathrm{BN}$ Rhizoctonia on these crops was moderate or low.

Soilborne fungal pathogens can cause economic yield losses on different plants in the countries, where vegetable cultivation is common. Therefore, suitable cultural practices, such as the use of resistant cultivars and the improvement of soil conditions, will be useful.

In addition, it is known that chemical control is not so efficient against Rhizoctonia spp. Therefore, it will be useful to determine biocontrol agents that could be effective against $R$. solani AG4 , and to evaluate their efficiency by in vivo and in vitro trials.

This work provided a better understanding of the Rhizoctonia spp. associated with bean, cucumber, eggplant, pepper and tomato plants and their rhizosphere soils in greenhouses in Samsun, the Black Sea region.

\section{ACKNOWLEDGEMENTS}

We gratefully acknowledge the support of funding by the Ondokuz Mayis University Research Foundation (PYO.ZRT.1904.11.016). 
RESUMO: Um total de cento e cinco isolados de Rhizoctonia pertencentes a 7 grupos de anastomose (AGs) foram obtidos a partir de raízes doentes e solos rizosféricos de plantas de feijão, pepino, berinjela, pimenta e tomate cultivados em estufas na província de Samsun (região do Mar Negro, Turquia) durante o período 2011-2012. Os isolados de Rhizoctonia spp. foram examinados por suas características culturais, grupos de anastomose e patogenicidade. Destes, 83,8\% eram Rhizoctonia solani multinucleadas (AG-2, AG-4, AG-5 and AG-6) e 16,2\% era Rhizoctonia binucleadas (AGA, AG-E and AG-F). Sessenta e cinco dos isolados pertenciam ao AG-4, que foi o grupo mais frequiente $(61,9 \%)$ em todas as estufas pesquisadas. O número de isolados pertencentes a AG-2 (7,6\%), AG-5 (6,7\%) e AG-6 (7,6\%) foi de 8, 7 e 8, respectivamente. Dezessete isolados recuperados de estufas pesquisadas foram identificados como Rhizoctonia binucleada AG-A (1,9\%), AG-E (6,7\%) e AG-F (7,6\%). Todos os isolados de Rhizoctonia spp. testados para taxas de crescimento cresceram a temperaturas de $10,15,20,25$ e $30^{\circ} \mathrm{C}$, enquanto que foram completamente inibidos a $5^{\circ} \mathrm{C}$. Os resultados dos testes de patogenicidade mostraram que as diferenças de virulência entre os isolados de Rhizoctonia spp. foram estatisticamente significativas $(\mathrm{P}<0,001)$. Os testes em mudas de feijão mostraram que a maior severidade da doença foi causada por isolados AG-4. O índice de gravidade da doença (do inglês, disease severity index - DSI) dos isolados de R. solani AG-4 variou de 3,2 a 3,8. Além disso, os isolados de três AGs pertencentes à Rhizoctonia spp. binucleadas foram geralmente encontrados como moderadamente virulentos (DSI 2,0-2,4).

PALAVRAS-CHAVE: Grupo de anastomose. Rhizoctonia spp. Podridão radicular. Legumes. Virulência.

\section{REFERENCES}

ANONYMOUS, 2015. Turkish Statistical Institute, Crop Production Statistics. <http://tuikapp.tuik.gov.tr/bitkiselapp/bitkisel.zul> [accessed 2003 2016]

DEMIRCI, E.; DOKEN, M. T. Anastomosis groups of Rhizoctonia solani Kühn and binucleate Rhizoctonia isolates from various crops in Türkiye. The Journal of Turkish Phytopathology, Izmir, v. 24, p. 57-62, 1995.

DEMIRCI, E. Rhizoctonia species and anastomosis groups isolated from barley and wheat in Erzurum, Turkey. Plant Pathology, Hoboken, v. 47, p. 10-15, 1998. https://doi.org/10.1046/j.1365-3059.1998.00214.x

EKEN, C.; DEMIRCI, E. Anastomosis groups and pathogenicity of Rhizoctonia solani and binucleate Rhizoctonia isolates from bean in Erzurum, Turkey. Journal of Plant Pathology, Pisa, v. 86, p. 45-49, 2004.

ERPER, I.; KARACA, G. H.; OZKOC, I. Characterization of Rhizoctonia species causing root-rot of cucumber plants in greenhouses in Samsun, Turkey, Proc. $2^{\text {nd }}$ Balkan Symposium on Vegetables and Potatoes. G. Paroussi et al. (eds.). Acta Horticulturae, Brisbane, v. 579, p. 531-534, 2002.

https://doi.org/10.17660/actahortic.2002.579.93

ERPER, I.; KARACA, G. H.; TURKKAN, M.; OZKOC I. Characterization and pathogenicity of Rhizoctonia spp. from onion in Amasya, Turkey. Journal of Phytopathology, Berlin, v. 154, p. 75-79, 2006. https://doi.org/10.1111/j.1439-0434.2006.01055.x

ERPER, I.; KARACA, G. H.; OZKOC, I. Identification and Pathogenicity of Rhizoctonia species isolated from bean and soybean plants in Samsun, Turkey. Archives of Phytopathology and Plant Protection, Abingdon, v. 44, p. 78-84, 2011. https://doi.org/10.1080/03235400903395427

ERPER, I.; AGUSTÍ-BRISACH, C.; TUNALI, B.; ARMENGOL, J. Characterization of root rot disease of kiwifruit in the Black Sea region of Turkey. European Journal of Plant Pathology, Dordrecht, v. 136, p. 291-300, 2013. https://doi.org/10.1007/s10658-012-0163-6

ERPER, I.; BALKAYA, A.; TURKKAN, M.; KILIC, G. Determination of fungal pathogens causing root and crown rot in winter squash (Cucurbita maxima Duch.) growing areas in the Black Sea region and reactions of some winter squash genotypes against these pathogens. The Anadolu Journal of Agricultural Sciences, Samsun, v. 30, p. 15-23, 2015. https://doi.org/10.7161/anajas.2015.30.1.15-23 
FAO. Food and agriculture organization. The database of annual production. FAOSTAT. Statistical database. <http://faostat.fao.org/site/567/DesktopDefault.aspx?PageID=567\#ancor> [accessed 2012 2015], 2012.

GONZALEZ GARCIA, V. G.; PORTAL, O. M. A.; RUBIO, S. V. Review, biology and systematics of the form genus Rhizoctonia. Spanish Journal of Agricultural Research, Madrid, v. 4, p. 55-79, 2006. https://doi.org/10.5424/sjar/2006041-178

HARATIANA, M.; SAFAIEA, N.; SHARIFNABIB, B.; MAHMUDIC, S. B.; ARIANAB, A. Genetic structure of populations of Rhizoctonia solani AG-4 from five provinces in Iran. Plant Pathology, Hoboken, v. 62, p. 649-656, 2013. https://doi.org/10.1111/j.1365-3059.2012.02665.x

JAISWAL, A. K.; ELAD, Y.; GRABER, E. R.; FRENKEL, O. Rhizoctonia solani suppression and plant growth promotion in cucumber as affected by biochar pyrolysis temperature, feedstock and concentration. Soil Biology \& Biochemistry, Oxford, v. 69, p. 110-118, 2014. https://doi.org/10.1016/j.soilbio.2013.10.051

KARACA, G. H.; OZKOC, I.; ERPER, I. Determination of the anastomosis grouping and virulence of Rhizoctonia solani Kühn isolates associated with bean plants grown in Samsun/Turkey. Pakistan Journal of Biological Sciences, Punjab, v. 5, n. 4, p. 434-437, 2002. https://doi.org/10.3923/pjbs.2002.434.437

LEWIS, J. A.; LUMSDEN, R. D. Biocontrol of damping-off of greenhouse-grown crops caused by Rhizoctonia solani with a formulation of Trichoderma spp. Crop Protection, Oxford, v. 20, p. 49-56, 2001. https://doi.org/10.1016/S0261-2194(00)00052-1

LOPEZ, A. V.; BOLANOS, B. T.; MORALES, M. J. Y.; PACHECO, R. P.; ESCALANTE, M. Q. Etiology of pepper wilt disease of 'Chile de Agua' (Capsicum annuum L.) in Oaxaca, Mexico. Revista Fitotecnia Mexicana, Estado Mexico, v. 32, p. 127-134, 2009.

MIRMAJLESSI, S. M.; SAFAIE, N.; MOSTAFAVI, H. A.; MANSOURIPOUR, S. M.; MAHMOUDY, S. B. Genetic diversity among crown and root rot isolates of Rhizoctonia solani isolated from cucurbits using PCR based techniques. African Journal of Agricultural Research, Nigeria, v. 7, n. 4, p. 583-590, 2012.

MITIDIERI, I.; MITIDIERI, D. The main diseases, which affect horticultural crops grown under cover in northern Buenos Aires. Acta Horticulturae, Brisbane, v. 357, p. 143-152, 1994.

https://doi.org/10.17660/ActaHortic.1994.357.13

MISAWA, T.; KUNINAGA, S. The first report of tomato foot rot caused by Rhizoctonia solani AG-3 PT and AG-2-Nt and its host range and molecular characterization. The Journal of General Plant Pathology, Ibaraki, v. 76, p. 310-319, 2010. https://doi.org/10.1007/s10327-010-0261-2

MUYOLO, N. G.; LIPPS, P. E.; SCHMITTHENNER, A. F. Anastomosis grouping and variation in virulence among isolates of Rhizoctonia solani associated with dry bean and soybean in Ohio and Zaire.

Phytopathology, St Paul, v. 83, p. 438-444, 1993. https://doi.org/10.1094/Phyto-83-438

ONDER, H. Using permutation tests to reduce type I and II errors for small ruminant research. Journal of Applied Animal Research, Abingdon, v. 32, p. 69-72, 2007. https://doi.org/10.1080/09712119.2007.9706849

SHARON, M.; KUNINAGA, S.; HYAKUMACHI, M.; NAITO, S.; SNEH, B. Classification of Rhizoctonia spp. using rDNA-ITS sequence analysis supports the genetic basis of the classical anastomosis grouping. Mycoscience, Amsterdam, v. 49, p. 93-114, 2008. https://doi.org/10.1007/S10267-007-0394-0

SNEH, B.; BURPEE, L.; OGOSHI, A. Identification of Rhizoctonia species. St Paul, USA, 1991. 133 p. 
SOLANKI, M. K.; KUMAR, S.; PANDEY, A. K.; SRIVASTAVA, S.; SINGH, R. K.; KASHYAP, P. L.; SRIVASTAVA, A. K.; ARORA, D. K. Diversity and antagonistic potential of Bacillus spp. associated to the rhizosphere of tomato for the management of Rhizoctonia solani. Biocontrol Science and Technology, Abingdon, v. 22, n. 2, p. 203-217, 2012. https://doi.org/10.1080/09583157.2011.649713

TUNCER, S.; EKEN, C. Anastomosis grouping of Rhizoctonia solani and binucleate Rhizoctonia spp. isolated from pepper in Erzincan, Turkey. Plant Protection Science, Prague, v. 49, p. 130-134, 2013.

VELÁSQUEZ, V. R.; VICTORIANO, L. F. Presencia de patógenos en almácigos y semilla de chile (Capsicum annuиm L.) en Aguascalien tes y Zacatecas, México. Revista Mexicana de Fitopatologia, Texcocov. 25, p. 75-79, 2007. 